Article

\title{
Implementing Electromobility in Public Transport in Poland in 1990-2020. A Review of Experiences and Evaluation of the Current Development Directions
}

\author{
Marcin Połom ${ }^{1, *(D)}$ and Paweł Wiśniewski ${ }^{2}$ (D) \\ 1 Division of Regional Development, Institute of Geography, University of Gdańsk, 80-309 Gdańsk, Poland \\ 2 Division of Landscape Research and Environmental Management, Institute of Geography, \\ University of Gdańsk, 80-309 Gdańsk, Poland; pawel.wisniewski@ug.edu.pl \\ * Correspondence: marcin.polom@ug.edu.pl
}

Citation: Połom, M.; Wiśniewski, P. Implementing Electromobility in

Public Transport in Poland in 1990-2020. A Review of Experiences and Evaluation of the Current Development Directions. Sustainability 2021, 13, 4009. https:// doi.org/10.3390/su13074009

Academic Editor: Giuseppe Inturri

Received: 28 February 2021

Accepted: 2 April 2021

Published: 3 April 2021

Publisher's Note: MDPI stays neutral with regard to jurisdictional claims in published maps and institutional affiliations.

Copyright: (c) 2021 by the authors. Licensee MDPI, Basel, Switzerland. This article is an open access article distributed under the terms and conditions of the Creative Commons Attribution (CC BY) license (https:// creativecommons.org/licenses/by/ $4.0 /)$

\begin{abstract}
Public transport has undergone major changes in recent years. In particular, they relate to the issue of environmental impact. Due to the significant emission of pollutants from the economy, in particular from the transport segment, member states of the European Union have taken measures to limit its scope. Only low-emission and zero-emission vehicles are to be used in transport, and mainly those that are powered by electricity in public transport. The development of battery technologies has led to a revolution in the range and operational capabilities of electric buses in the last decade. They have become a seemingly easy alternative to traditional electric vehicles in public transporttrams and trolleybuses. This article presents the possibilities and limitations of the development of public transport in Poland based on electric buses. An attempt was made to review the literature and compare the possibility of the functioning of buses, trams and trolleybuses in the Polish socioeconomic, environmental and technological conditions. The article was based on a literature query, an analysis of unpublished materials, and a qualitative analysis of national programs endorsing the idea of electromobility as well as an online survey on the perception of electric public transport. The main goal of the article was to identify and evaluate the possibilities of developing public transport in Poland with the use of electric buses. The main results of the work include the demonstration that the optics of the national and regional authorities in Poland are focused mainly on electric buses without a thorough analysis of the legitimacy of their operation, especially in small towns. The incentive in the form of subsidizing the purchase of an electric bus is sufficient for them, and the future effects of using electric buses are not investigated.
\end{abstract}

Keywords: public transport; electromobility; sustainability; electric bus; trolleybus; tramway

\section{Introduction}

Public transport remains a very important segment of the economy. It meets the daily needs of mobility, and at the same time it can play an important role in reducing environmental pollution. Climate changes influence international and national policies to reduce $\mathrm{CO}_{2}$ emissions and pollution in densely populated areas. The functioning of electricity-powered public transport in cities improves living conditions [1]. The contemporary development of drive technologies, in particular alternative power sources (on-board batteries), creates new possibilities for the use of electric buses and trolleybuses [2]. Many countries support and even require the purchase of only electric vehicles. In addition, Poland responds to these postulates [3-6]. It is still important to search for the most perfect solutions and to obtain the best, lasting effect in public transport [7].

Scientific research on electromobility in the countries of Central and Eastern Europe is limited in its scope. Currently, research on the validity of introducing electric buses into operation is dominant [8-13]. However, there are no summary studies on transport policy or comparative studies that would assess the legitimacy of the undertaken actions [14,15]. 
In Poland, scientific publications on electric buses also dominate, in particular, publications on restrictions and possibilities of putting them into operation [16-18]. Scientific studies dealing with tramway and trolleybus transport appear less frequently, although the latter is an especially good alternative to electric buses. Eastern European cities that have trolleybus transport often underestimate it, although the available technological solutions often allow for the transportation service of the entire city using trolleybuses with on-board batteries [19-21]. The use of trolleybuses with on-board batteries reduces their weight, does not reduce their capacity too much, and at the same time reduces operating costs in the future, e.g., when there is a need to replace the batteries [22,23]. With the existing traction infrastructure, it is much easier to develop an electric transport system than to build it from scratch [24].

This study was prepared having in mind the need for a synthetic summary of the Polish road to the development of electric public transport and responding to the postulates of the European Union regarding the reduction of emissions of $\mathrm{CO}_{2}$ and other pollutants. It has several goals: (i) to systematize information on legal actions, (ii) to present solutions that respond to legal regulations, (iii) to obtain answers to several research questions related to the quality of the implemented law and instruments supporting the development of electric public transport, and (iv) to identify the social perception of electric public transport. The article combines quantitative and qualitative analyzes of electromobility development policies in public transport with a survey conducted among residents. This attempt to combine two different issues, seemingly related to different issues, was aimed at checking to what extent the transport development policy based mainly on electric buses has consequences in building respondents' awareness.

Several research questions have been formulated in the article:

1. Do legislative activities in Poland meet the needs of transforming public transport postulated in the European Union legislation?

2. When designing urban electric transport development, do cities/transport operators take into account future operating costs sufficiently?

3. Do the activities supporting the development of electric public transport treat electric buses and trolleybuses equally?

4. What is the quality of government programs endorsing the purchase of rolling stock for public transport?

5. Do electric buses play an important (key) role in the public transport system in the public awareness?

6. Does the society perceive the development of electric public transport as a way to improve the environment and the living conditions?

\section{Scientific Background}

\subsection{Electric Public Transport in the Concept of Sustainable Development in the European Union}

The idea of sustainable development is now implemented in all sectors of the economy. The fact that transport-related targets are included in eight out of the seventeen proposed Sustainable Development Goals (Goals 2, 3, 6, 7, 9, 11, 12,13) illustrates the cross-cutting role that this sector has in sustainable development [25-28]. The goals and measures to ensure transport development are indicated in the most important strategic documents concerning the transport and climate policy of the European Union. Taking environmental protection into account, transport is, inter alia, one of the priority objectives of the Seventh General EU Environment Action Program to 2020 [29] adopted by the European Parliament and the Council of the European Union. Actions aimed at modernizing the transport sector and reducing its share in $\mathrm{CO}_{2}$ emissions and increasing its competitiveness, including by building the infrastructure for electric mobility networks, are in line with the objectives and priorities of the Europe 2020 strategy for smart and sustainable development [30]. Key elements of EU initiatives and plans to decarbonize and improve energy efficiency through the development of efficient and low-carbon transport systems also include: Energy Roadmap 2050 [31], the roadmap for moving to a competitive low-carbon economy 
by 2050 [32] and the 2011 White Paper on Transport [33]. The Transport White Paper is currently one of the most important documents on the EU transport policy, assuming the development of a competitive and sustainable transport system by supporting mobility and reducing emissions by $60 \%$, creating an effective network of multimodal travel and transport between cities, ensuring a global level playing field for travel in long-distance and intercontinental transport of goods, and the provision of clean urban transport and commuting. The specific objectives adopted in the White Paper assume, inter alia, the elimination of conventionally powered cars from cities by 2050 as well as the development of the electromobility concept, which is also referred to in the European Commission's 2013 communication on joint efforts to achieve competitive and resource-efficient urban mobility [34]. The development of low-emission mobility as an important element of the modernization of the EU economy, contributing to the reduction of emissions in the transport sector and the fulfillment of the EU's commitments in the Paris Agreement, is also a goal of the latest strategic document in the field of sustainable transport, adopted by the European Commission-the European Strategy for Low-Emission Mobility [35]. It assumes optimization of the transport system and increasing its efficiency, increasing the use of low-emission alternative energy sources for transport, and the development of zero-emission vehicles. The strategy recommends the use of electric drive, first of all in public transport in urban areas [26].

\subsection{Idea of Electromobility in Public Transport in Poland}

Poland's response to the postulates of the European Union policies in terms of reducing emissions of pollutants into the atmosphere in the main branches of the economy, and therefore in the transport segment in particular, is to direct the development vector towards electromobility understood as the development of zero-emission transport, both as regards individual and collective vehicles.

As part of meeting the challenge of lower emissions to the environment, in particular of $\mathrm{CO}_{2}$ to the atmosphere, the Polish government focused the development of the transport sector on electromobility. The assumption is that this goal is to be linked to the development of the domestic automotive industry, which is to provide carriers with electric vehicles. The program of support for the development of electric bus technologies and their subsequent deliveries to city carriers was named E-Bus in the Government's Strategy for Responsible Development, which sets the direction for Poland's economic development for the coming years. The assumptions of the program included financing the research and development work (financed by the National Center for Research and Development), which should result in the Polish electric bus. Perhaps this seems difficult to understand, since there are already several manufacturers of electric buses and trolleybuses in Poland. In fact, it was assumed that a completely new electric bus would be built. In free-market Poland, this is a return to a centrally controlled economy.

The goal of the Polish policy is the widest possible use of electric buses in public transport. However, the possibility of building other electrified transport systems (tramways and trolleybuses) is ignored. In order to facilitate the purchase of electric buses for various cities, programs financed from budgetary and external funds are implemented, but they often prevent their use for the development of the existing electric public transport.

It should be mentioned that sustainable mobility plans, which are prepared by individual municipalities, play an important role in the development of a more environmentally and friendly to inhabitants of public transport. The qualitative change in this respect took place along with the period of preparation for accession to the European Union. Cities then began to implement integrated plans for the development of urban transport. In the following years, these documents were updated and contained ever more restrictive $\mathrm{CO}_{2}$ and pollution standards.

In December 2019, the European Commission has published its Communication on the European Green Deal, which includes an action plan to make the EU's economy sustainable, boost the efficient use of resources by moving to a clean, circular economy, 
and restore biodiversity and cut pollution [36]. The European Green Deal seeks a 90\% reduction greenhouse gas emissions in transport by 2050. Automated mobility and smart traffic management systems are expected to make transport more efficient and cleaner. The Green Deal will address emissions, urban congestion, and improve public transport. One year later, in December 2020, the European Commission presented its Sustainable and Smart Mobility Strategy together with an Action Plan of 82 initiatives that will guide work for the next four years [37]. The strategy stresses that the most serious challenge facing the transport sector is to significantly reduce its emissions and become more sustainable. Greening mobility must be the new license for the transport sector to grow. It is crucial that mobility is available and affordable for all, that rural and remote regions are better connected, accessible for persons with reduced mobility and persons with disabilities, and that the sector offers good social conditions, reskilling opportunities, and provides attractive jobs.

\section{Methods and Data}

The article presents a multi-level study that was divided into five stages, assigning appropriate methods to each of them (Table 1). In particular, the analysis was based on the collection and analysis of available literature sources, scientific studies, unpublished documents and reports. Original figures showing the state of development of urban electric transport in Poland were prepared. The work also uses an online survey, whose synthesis is presented in the article.

Table 1. Research stages, relevant detailed aims, materials and methods.

\begin{tabular}{lll}
\hline Stage & Research Goals & Materials and Methods \\
\hline 1 & $\begin{array}{l}\text { Characteristics of the functioning of electrified } \\
\text { public transport (operational experience, } \\
\text { development of tramway and trolleybus transport) }\end{array}$ & $\begin{array}{l}\text { Materials: data of transport operators (Public Transport } \\
\text { Authority) and the results of an expert opinion on the } \\
\text { functioning of public transport in Poland } \\
\text { Methods: query of materials and scientific sources, } \\
\text { quantitative temporal and spatial analysis }\end{array}$ \\
\hline $\begin{array}{l}\text { Identification of conditions for the development of } \\
\text { electric public transport (electric buses, tramways } \\
\text { and trolleybuses) }\end{array}$ & $\begin{array}{l}\text { Materials: data of operators and carriers of public transport } \\
\text { development of the idea of electromobility in public } \\
\text { transport in Poland; evaluation of city policies in the field of } \\
\text { implementing the idea of electromobility on the basis of } \\
\text { undertaken investment activities }\end{array}$ \\
\hline $\begin{array}{l}\text { Identification of the social perception of electric } \\
\text { public transport }\end{array}$ & $\begin{array}{l}\text { Materials: structured internet survey } \\
\text { Methods: quantitative and qualitative analysis of the results } \\
\text { of the internet survey }\end{array}$ \\
\hline $\begin{array}{l}\text { Synthesis the possibilities and limitations of the } \\
\text { development of public transport based on electric } \\
\text { buses }\end{array}$ & $\begin{array}{l}\text { Materials: scientific publications, reports on the } \\
\text { implementation of the idea of electromobility and } \\
\text { sustainable development in public transport } \\
\text { Methods: quantitative analysis of the results of internet } \\
\text { surveys and qualitative analysis of the conditions for the } \\
\text { functioning of the law in the field of electromobility, } \\
\text { including government projects }\end{array}$ \\
\hline
\end{tabular}

\section{Development of Electric Public Transport in Poland in 1990-2020}

Electric public transport in communist Poland played a significant role until 1989. The underdevelopment of individual motorization and problems with fuel supplies drew the attention of central authorities to electric transport. The Polish power industry powered by domestic lignite and hard coal mines gave a feeling of greater stability than transport based on diesel buses. Worldwide fuel crises even further directed the development of electricity-based transport in cities. After World War II, first the production of trams was organized in Poland, and since the 1970s also of trolleybuses. The 1970s and 1980s was a 
period of great plans for the development of public transport and its electrification in many cities in Poland. However, economic constraints affected these ventures.

The turn of the 1980s and 1990s brought Poland a socio-economic transformation, whose consequence was the departure from centrally financed public transport in cities in favor of transport organized and financed by local authorities. In 1990, five trolleybus transport systems and 14 tramway networks operated in Poland (Figure 1) [38-40]. The economic decline of the 1990s, the underinvestment in the infrastructure and the rolling stock led to the closure of two trolleybus systems in Słupsk and the route connecting Warsaw and Piaseczno. The tram transport systems survived the difficult period, but the network coverage was systematically reduced. In particular, this process concerned suburban tramways in Łódź and tramways in the Katowice Agglomeration. In 1995, the first subway line in Warsaw, which had been under construction for several years, was launched.

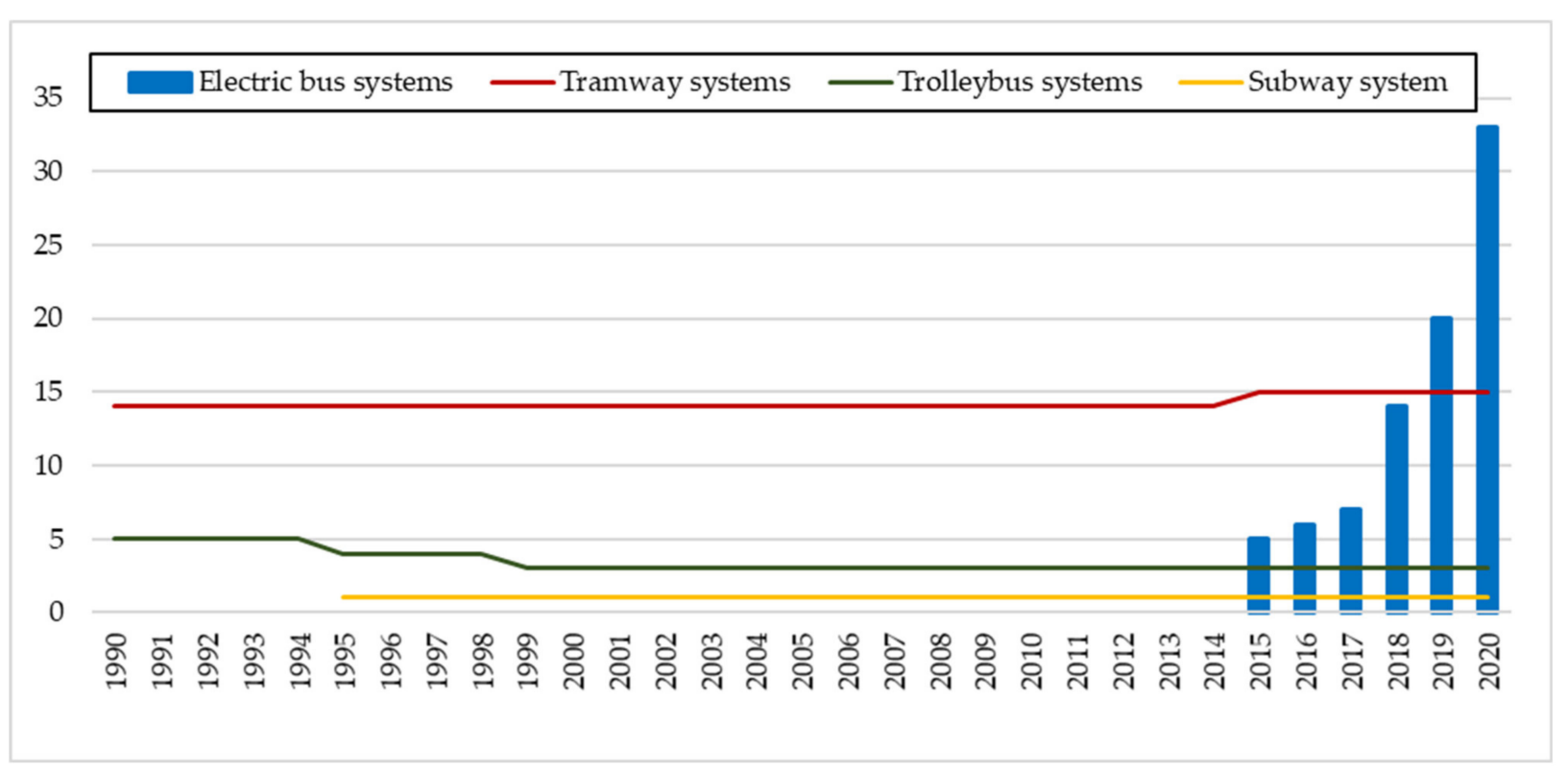

Figure 1. Number of electric public transport systems in Poland in 1990-2020.

The real breakthrough in public transport in Poland came with the appearance of the European Union pre-accession funds, and then as a result of Poland's accession to the European Union and its inclusion in the cohesion fund. The electric public transport systems in cities which were in a very poor technical condition gained a possibility to finance the necessary infrastructure and rolling stock investments from external sources. In 2004-2020, all existing tramway and trolleybus transport systems in Poland underwent the process of modernization, and often a significant expansion of connections [41,42]. In 2015, a new tramway system was launched in Olsztyn (Figure 1).

Despite significant funds flowing to Poland from the European Union budget, no city apart from Olsztyn decided to build a new electric transport system. Although there were plans to build a trolleybus system in Zielona Góra and tramway transport, e.g., in Płock, none of the cities took such measures [43]. In practice, since 2015, such plans have even ceased to be discussed, due to a new alternative in the form of electric buses, which, according to local authorities and carriers, can be easily implemented into the city's transport system. Since the commissioning of the first electric buses in Poland in 2015 till the end of 2020, the process of implementing this type of vehicles was very dynamic. In 2015, such buses ran in 5 cities, and in 2020 already in 33 (Figure 2). Numerous cities also declared their willingness to implement electric buses in public transport. These were both very small towns and very large cities that already had another electric transport system [44]. 


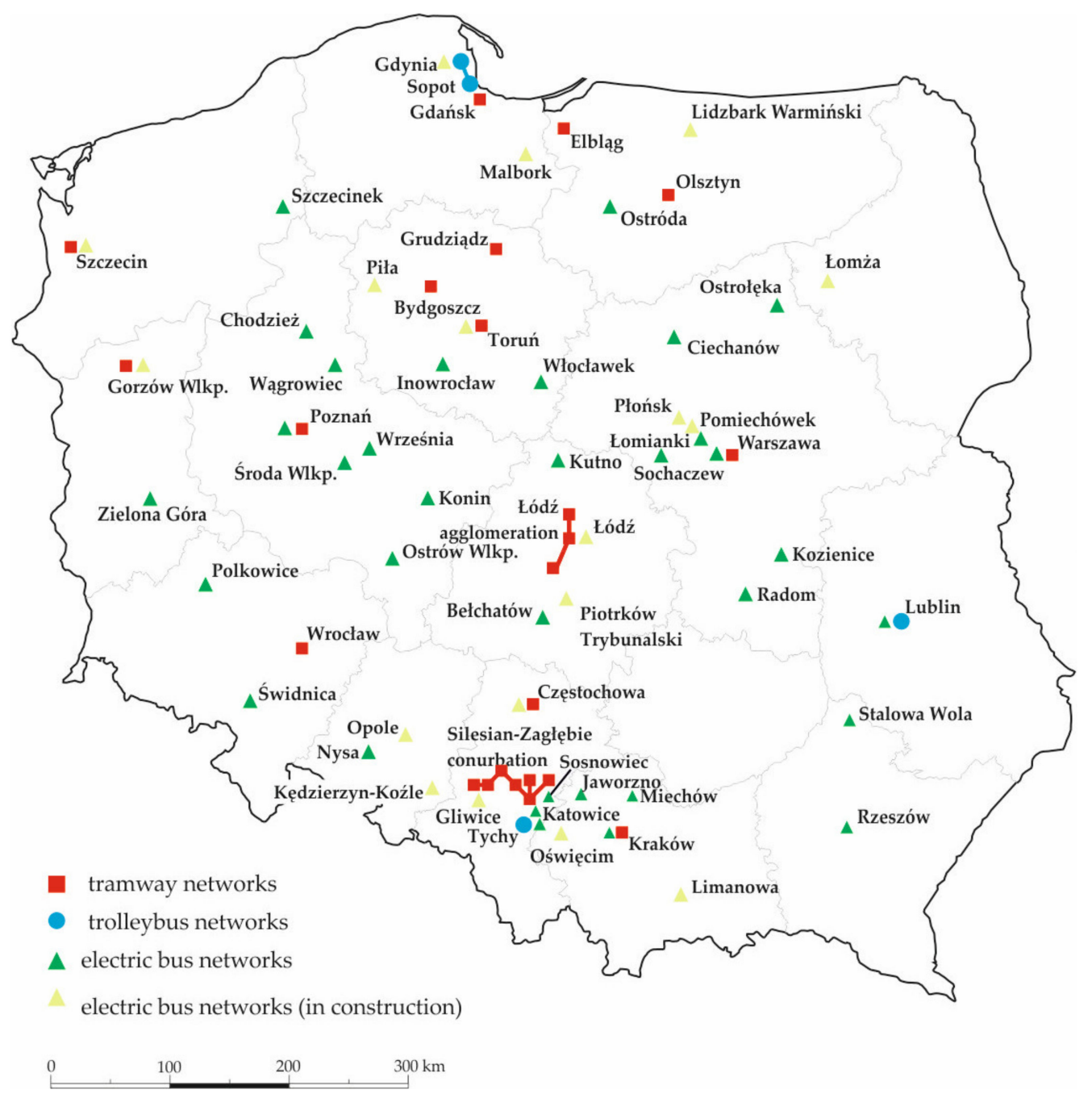

Figure 2. Electric public transport systems in Poland in December 2020.

In the case of large centers that had, for example, tramway systems, the combination of their advantages with the possibility of replacing diesel buses powered by electricity should be assessed positively, while in the case of cities with trolleybuses, such actions are questionable and may threaten the functioning of trolleybus transport in the long run. In the case of smaller towns, the purchase and operation of electric buses was primarily dictated by the ease of obtaining funds without in-depth studies of the justification. The policies of cities willing to introduce electric buses were more or less similar. With the current scientific knowledge about battery life, it should be expected that they would need to be replaced at least once in the vehicle's life cycle of 12-15 years. While cities and carriers obtain funding for the purchase of electric buses, in the event of a later need to replace the batteries, the lack of allocated funds may prematurely preclude such vehicles from use.

The domestic production of vehicles was the main support for the development of electrified transport in Poland. After the political changes, many foreign bus manufacturers moved their production to Poland. An important place in this process was taken by a domestic company derived from the German Neoplan-Solaris Bus and Coach, which produced diesel buses, then trolleybuses and trams, as well as electric buses $[45,46]$. Other manufacturing companies in Poland also started producing electric buses. Foreign manufacturers, e.g., the Czech SOR and the Chinese BYD, also made attempts to supply such vehicles to Poland. Out of 33 Polish cities with electric buses, Solaris buses operate in 27, another Polish brand Ursus in 4, in 2 the Czech brand SOR, as well as Automet and MMI in individual cities. 


\section{Experience in Implementing Electromobility in Public Transport in Poland in} Recent Years

\subsection{National Legal Framework}

In order to achieve the objectives related to reducing the emission of pollutants by the transport sector, in particular by public transport, measures have been taken in Poland to adjust the law to the EU law adopted in the Directive of the European Parliament [47]. In March 2017, the Council of Ministers adopted a strategic document entitled "National Framework for the Policy of Development of Alternative Fuel Infrastructure" [48]. This document specified that one million electric vehicles should be in service by 2025 . However, no specific types of vehicles were identified. The most important provisions of the document include (i) the need to use low-emission vehicles by enterprises providing public services, (ii) supporting the development of public collective transport by implementing low-emission public transport means and their power supply. A total 32 agglomerations and densely populated areas are the main recipients of the new law, as those in which it is compulsory to replace public transport with low-emission or zero-emission one. As part of the document [48], it was indicated that tenders for the implementation of collective public transport services must promote pro-ecological solutions, i.e., the use of low-emission vehicles.

Endorsing the development of public transport based on low-emission solutions is to be connected with:

1. support for the construction of fast chargers for electric buses,

2. financial support (including the construction of chargers),

3. legislative support (e.g., facilitating the investment process) [49].

The next step in the development of the law on the use of low-emission means of transport, including those fully powered by electricity, in Poland is the Act of 11 January 2018 on Electromobility and Alternative Fuels [50]. It is the implementation of the EU law expressed in Directive 2014/94/EU. Similarly to the previously mentioned "National Framework ..." ", the Act deals with the subject of low-emission transport, including the development of the market of electric vehicles. The document specifies:

1. conditions for the development and rules for the deployment of alternative fuels infrastructure in transport,

2. rules for the provision of services of charging electric vehicles,

3. obligation to use zero-emission (electric) vehicles by public sector companies.

Similarly to [48], also the Act on electromobility deals with both passenger cars and collective urban transport (electric buses, trams, trolleybuses). The Act defines specific requirements for communes and counties (all counties with over 50,000 inhabitants) regarding the use of zero-emission vehicles. Pursuant to the provisions of the Act, a specific percentage of vehicles to be reached in each year was specified [50]. Work is currently underway on the amendment [50]. The proposed changes are intended to endorse the development of electromobility and alternative fuels infrastructure even better, and thus encourage consumers to buy vehicles powered by these fuels.

\subsection{National Programs Endorsing the Development of Electromobility in Public Transport 5.2.1. Gazela-Low-Emission Urban Transport}

In addition to national and EU funds, which had thus far supported the reconstruction and development of public transport in Poland, a decision was made to create a program that would be specifically dedicated to reducing emissions in public transport by supporting the purchase of environmentally friendly vehicles. The first project of this type was called Gazela-low-emission urban transport, which, with a budget of PLN 80 million, expected a possibility to subsidize up to $100 \%$ of the eligible costs of the project. The program was based on the sale of $\mathrm{CO}_{2}$ emission rights to Spain. The proceeds from this transaction had to be allocated to the purchase of non-standard gas-electric buses, which are practically exclusively produced by Spanish manufacturers. Two applications were 
recommended for financing: the purchase of standard-length and articulated buses for Częstochowa (40 vehicles in total) and standard buses for Gdynia (10 vehicles). Projects from both cities exhausted the full pool of available funds. Both transport operators that became beneficiaries faced problems in selecting vehicle manufacturers. As a result, the production for Czestochowa was undertaken by the Polish manufacturer Solbus, whose vehicles were faulty and were quickly withdrawn from use after a serious fault which resulted in burning down of one of the vehicles. In Gdynia, despite several tenders, a contractor could not be selected, and the carrier abandoned the project. In Czestochowa, buses were stopped in 2017, and only in 2020, one of them was prototypically rebuilt by Autosan. After supervised operation, a decision was made to rebuild further 24 vehicles to achieve the environmental effect assumed in the project. In the event that the full range of vehicles could not be put back into operation, Częstochowa decided to lease 15 electric buses to complement gas-electric buses [51]. Difficulties in conducting the project and obtaining the effect in the form of $\mathrm{CO}_{2}$ emissions to the atmosphere consisted mainly in the requirement to purchase unusual vehicles, unavailable on the market. The risk of preparing a prototype with relatively small purchases was significant. Producers did not take such action, and the only one that took the risk does not exist anymore. In the following years, attempts were made to announce the Gazela BIS program for loans for the purchase of gas-powered buses, but also this program did not end positively.

\subsubsection{Gepard-Emission-Free Public Transport}

After the unsuccessful "Gazela" program, the National Fund for Environmental Protection and Water Management prepared a new project to support the purchase of electric buses, named "Gepard". There were two editions of this program. For the first one, the call for applications took place in September 2017. A total of PLN 200 million was allocated to subsidize the purchase of electric buses (PLN 41 million as a non-returnable subsidy and PLN 159 million as loans) [52]. In the first edition of the program, only six applications for a subsidy and one application for a loan were submitted from Gdynia, Inowrocław, Polkowice, Poznań, Szczecin and Świdnica. The sum of applications for subsidies was less than PLN 28 million, and for loans less than PLN 5 million. These amounts meant that only $68 \%$ and $3 \%$ of the budget was used up. The total cost of these projects was approximately PLN 90 million. The lack of much competition among local government units could indicate concerns related to the "Gazela" program, as well as the still uncertain technology of electric buses. After evaluation, five applications for a total of 30 vehicles were submitted for funding. The application submitted by the city of Świdnica was assessed negatively [53].

The way the tender was constructed favored only those cities that wanted to buy electric buses. The inability to co-finance trolleybuses, which are fully functional equivalents of such vehicles, led to the situation that the city of Gdynia applied for the purchase of 6 vehicles, which are de facto trolleybuses, but in reality they were approved twice as electric buses and as trolleybuses.

In the second edition of the "Gepard" program, the regulations were modified, which provided for support only for cities with up to 100,000 inhabitants. It had a budget of PLN 168 million and allowed submitting applications both by local government units and carriers providing services in such cities. Over PLN 19 million was allocated to nonreturnable subsidies, and over PLN 149 million to low-interest loans. It was possible to obtain a subsidy of up to $60 \%$ of eligible costs and of up to $100 \%$ of costs between the amount of the subsidy and the eligible costs of the project. The call for applications took place at the end of 2018. Just as in the first edition of the program, the value of submitted applications did not exhaust the available funds. In total, seven applications for subsidies and 1 for a loan for a total amount of over PLN 21 million were submitted, which is only $12.5 \%$ of the available budget. Out of five applications for subsidies and one for loan, three projects were selected for financing in Kozienice, Łomianki and Świdnica, which expected the purchase of only six buses [54]. 
The lack of greater interest in applying for funds under the second call for the "Gepard" program proves its poor preparation, in particular, a relatively small share of funds for nonreturnable subsidies in the budget. Due to the necessity to build infrastructure, charging stations and adaptation of technical facilities, the program was not very attractive for small towns.

An additional element of the second call under the "Gepard II" program was a special pool of funds allocated to cities of the Silesian Voivodeship. In October 2019, the authorities of the Silesian Voivodeship and representatives of the National Fund for Environmental Protection and Water Management signed an agreement on combining funds from the "Gepard II" program with EU funds at the voivodeship's disposal under the "Program for Silesia". There were two calls: one for the central sub-region and the other for the southern sub-region. In total, six applications for a subsidy for the amount of PLN 57 million and three applications for a loan for the amount of PLN 6.5 million were submitted. The budget set aside in this part of the "Gepard II" project was PLN 70 million, so the applications consumed it almost completely. Ultimately, three projects were selected for funding, for the purchase of forty vehicles for the Górnoślasko-Zagłębiowska Metropolia (Metropolis GZM), six buses (and de facto trolleybuses) for Tychy and four buses for Zawiercie [55].

\subsubsection{Green Public Transport}

"Green Public Transport" is a new project announced by the National Fund for Environmental Protection and Water Management. Its purpose is to co-finance activities in collective public transport that reduce the use of emission fuels. Within the framework of the program, the purchase of new electric buses, hydrogen buses or trolleybuses may be subsidized. In the case of trolleybuses, in the first phase of recruitment, they were additionally required to be equipped with a drive system that would allow them to travel through sections without a traction network. The second option was to subsidize the modernization or construction of a new infrastructure allowing the use of the purchased vehicles (charging stations for electric bus, hydrogen refueling stations and the traction network) [56]. The "Green Public Transport" project provides for a possibility of subsidizing up to $80 \%$ of the purchase costs of new electric buses and trolleybuses and up to $90 \%$ of the costs of new hydrogen buses, and up to $50 \%$ of the costs of modernization or construction of infrastructure.

The new program was structured in a simple manner. From the moment of announcing the call for applications, they were accepted until the available financial resources were exhausted. This solution was to facilitate the process and encourage cities and transport companies to apply for subsidies. In fact, it violated sound competition rules, as smaller companies applying for a moderate number of vehicles were privileged. It was easier for them to prepare for the tender and submit their applications quickly. Large cities preparing more extensive programs of renewing the vehicle fleet did not have a chance to make it by the time the budget had run out. The tender was launched for the period from 04 January 2021 to 15 December 2021, but in fact the amount of available funds was exhausted on 18 January 2021 [57]. The project's budget was PLN 1.1 billion. Initially, it was expected that there would be three call for proposals. The second was to start on 3 January 2022, and the third, on 2 January 2023. Due to the rapid depletion of the available funds, it was announced immediately after the closure of the first call for proposals that the next phase would be brought forward to the fall of 2021.

All applications submitted in just two weeks concerned the purchase of 431 vehicles. Applications concerning the purchase of electric buses dominated with a total of 322 . Moreover, the purchase of 102 hydrogen buses and 7 trolleybuses was planned. The applications came from various cities and entities, as presented in Figure 3. The largest complex project came from Poznan and regarded the purchase of 84 hydrogen buses with the accompanying infrastructure. A project from Krakow for 40 electric buses placed second. Further applications were made for a smaller number of vehicles. Particularly noteworthy is the small town of Chełm, which applied for subsidizing the purchase of 15 electric buses and 15 hydrogen buses with the additional infrastructure. Small towns 
dominated among the applicants. Three of them are very small towns (less than 20,000 inhabitants): Chodzież, Łomianki and Ząbkowice. Towns with up to 100,000 inhabitants constituted the most numerous group-18 of them. Large cities (from 100,000 to 500,000 inhabitants) were represented by seven of them, and five applications were submitted by very large cities (over 500,000 inhabitants), including one metropolitan union. In total, 33 applications were submitted in the first phase of the call for proposals.
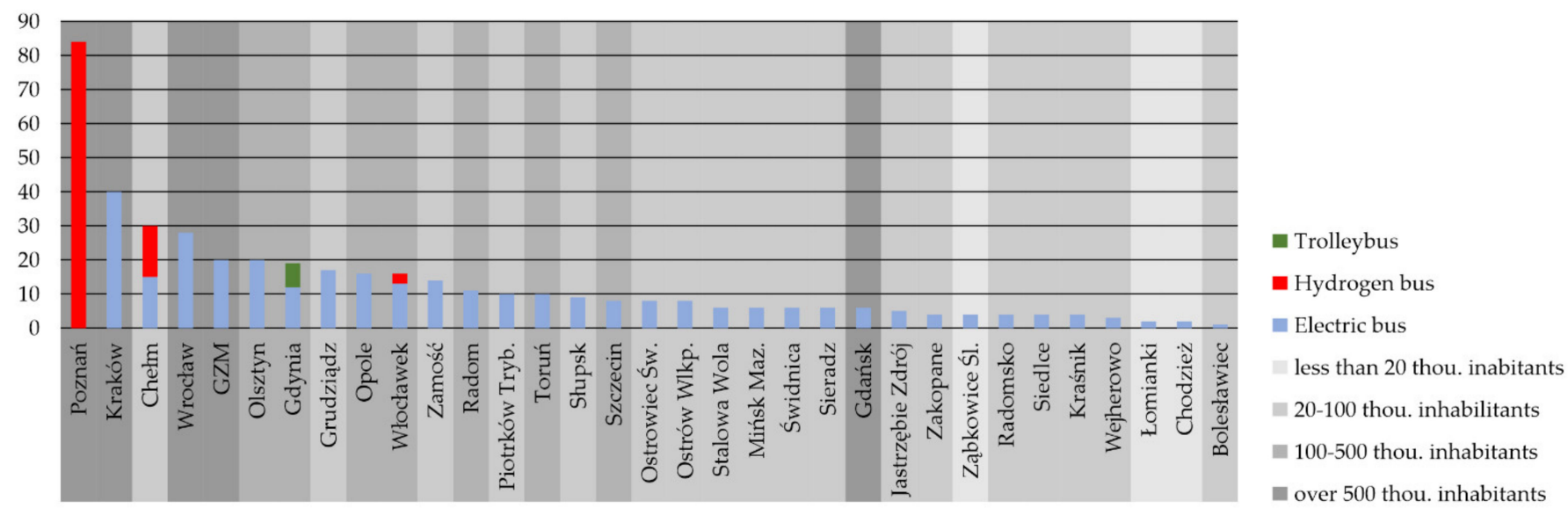

Figure 3. Projects aggregated to cities, submitted under the Green Public Transport Program in Phase I in 2021 (GZMGórnośląsko-Zagłębiowska Metropolis).

The idea of the project refers to the policy of developing public transport that uses alternative fuels and low- or zero-emission vehicles. However, the way of preparing and conducting the tender is debatable. Due to the adopted rules, the beneficiaries applying for minor tasks were in a privileged position. In the event of a need to plan infrastructure, the situation was significantly more difficult. Local governments and carriers that applied for subsidies probably prepared their ideas spontaneously. This is exemplified by Chełm, which wants to introduce two more types of vehicles to transport services, in addition to diesel buses already in operation. Even without in-depth studies, one can easily conclude that three types of vehicles in a small town may impede their daily operation and worsen the balance of public transport functioning. In the next editions of the project, a reduced percentage of subsidies has been planned.

\section{Models of Implementing Electromobility in Public Transport in Poland in the Second Decade of the 21st Century}

Certain regularities, repeated in most cities in recent years, can be noticed in analysis of the decisions on the development of urban electric transport in Poland. The construction or expansion of the classic urban electric transport system (tramway, trolleybus) requires significant financial outlays, which discourages local authorities from such activities. However, high construction costs are often compensated in the long run by lower operating costs. However, to confirm this, independent multi-criteria analyses are necessary. Due to the formal requirements, in particular of the European Union funds, such documents are drawn up, but most of them are not prepared reliably. The suggestiveness of the contracting entities of such studies affects the actual way of their preparation. City authorities expect the cheapest way to achieve goals that sometimes become political goals. The construction of a tramway or trolleybus system, in addition to economic requirements, e.g., in terms of passenger flows, is also associated with a long period of coming into existence. It is impossible to introduce such vehicles to the city's service "overnight". The process of designing and implementing infrastructure requires several years of preparation. One of the potential advantages of introducing electric buses to urban transport is the relatively short period of implementation, actually related to the time of manufacturing and delivering the vehicles. This potentially positive aspect is often the main argument for the authorities 
of large urban centers. The remaining arguments are not very relevant then. However, addressing the issue of public transport development in this way leads to fundamental distortions and may limit or even lead to a decline in zero-emission public transport in the city in the long run. Tramway or trolleybus investments, although initially much more expensive, have an advantage that electric buses do not have- - they are much more durable and to a greater extent guarantee the maintenance of environmentally-friendly transport in the city. The ease and short period of introducing electric buses into service are associated with the same features in the event of decommissioning from the city service.

6.1. Patterns of Actions Taken by Local Authorities Regarding the Development of Electric Public Transport in Poland after Poland's Accession to the European Union

Summing up the experience of Polish cities in the implementation of electromobility in public transport so far, two generalized patterns can be distinguished-a positive and a negative one:

I. The model of positive action (good road map):

(a) a preliminary decision on the construction or expansion of urban electric transport,

(b) preliminary activities (multi-criteria analysis of the justification of the investment; a stage taking into account the costs of operating the system for at least 20 years),

(c) the final decision to build, expand or not to take action as regards urban electric transport,

(d) effects in the form of an optimal means of public transport in the city with the highest economic efficiency and the lowest environmental impact which can be maintained and developed in a sustainable manner;

II. The model of negative actions (bad road map):

(a) an initial decision to build or expand urban electric transport, with the initial assumption expecting it to be the electric bus,

(b) no preliminary actions or pretend actions (no sufficiently in-depth studies on traffic conditions, economic effects, investment sustainability, etc.),

(c) the final decision to build an electric bus system,

(d) effects in the form of a means of transport mismatched to the functioning of the city, difficulties in maintaining electric buses in the long run, etc.

The above models reflect the two most common approaches in programming the development of electromobility in public transport in Poland. The ease of obtaining funds for the purchase of new electric buses puts pressure on the beneficiaries to quickly prepare a plan/project for their implementation. In fact, electric buses appear in localities and operate on lines that are not predisposed to operate electric buses. Due to the reactivity of local government authorities' actions, in particular in small urban centers, the most commonly the negative model of action appears.

\subsection{Characteristics of City Policies That Fit into Development Models}

\subsubsection{Olsztyn (Construction of a New Tramway System)}

Olsztyn is one of the voivodship capitals in Poland, with over 170,000 residents. Significant passenger flows allowed the city authorities to consider launching electric public transport. The mayor of Olsztyn has repeatedly emphasized that electric transport enhances the importance of the city. He has made it clear many times that he would only consider building a network of tram connections. The activities of the municipal authorities have been conducted since 2006. In 2009, a feasibility study was presented for the project of public transport development in Olsztyn, in which building a tramway network was considered the most appropriate $[40,58]$. It is worth noting that both trams (until 1965) and trolleybuses (until 1971) had already operated in Olsztyn. However, they were liquidated as a result of the decline in urban electric transport. The initial feasibility studies for the construction of 
a new ecological transport system in Olsztyn assumed the possibility of using trams, trolleybuses and gas buses. Incorrectly assumed costs of building the infrastructure (similar values for tramway and trolleybus transport) favored tramways. Such assumptions should be considered as politically driven, because the then mayor of Olsztyn repeatedly presented his point of view in the local media even before the results of the expert opinion were disclosed. As a result, a tramway system was created in Olsztyn to serve only a part of the city. In view of the data from the other three trolleybus systems existing in Poland, for a comparable amount, practically whole Olsztyn could be served; therefore, the availability of zero-emission transport would be much better, and the inhabitants would gain even coverage of the city area with a network of ecological connections.

The decision to build a tramway system also has consequences for its subsequent operation. Tramway transport in Olsztyn was affected by two key issues. Firstly, there is a need for further expansion of the network to make electric public transport available to other city residents. This is associated with high construction and operating costs, and as a result may contribute to the collapse of public transport in a medium-sized city. This would be an example of a mismatch between the scale of the transport system and passenger flows, as well as the ability to finance it. Secondly, the introduction of a tramway system without separation of the tracks on part of the route resulted in road difficulties which provoked public criticism $[59,60]$. However, in the opinion of the Olsztyn municipal authorities, trams have become its brand, and they prioritize the further expansion of the only route, which is served by three alternative lines [61].

6.2.2. Gdynia, Lublin and Tychy (Introduction of Electric Buses to Operation in Cities with Extensive Trolleybus Infrastructure)

Trolleybus transport is not a common means of urban transport in Poland. There are three systems in operation today: in Gdynia, which also serves the city of Sopot, and also in Lublin and in Tychy [39]. As a result of systematic acquisition of funds from the European Union, all of these systems have undergone enormous organizational and functional changes. In 1999, the trolleybus transport in Tychy was in danger of liquidation, and a social defense committee was organized to maintain it. At the beginning of the 21st century, the legitimacy of maintaining trolleybuses in Gdynia was discussed. Nowadays, trolleybus transport in Poland is indicated as an example of model transformation using the latest available technologies in the field of power supply, modernization of traction infrastructure and rolling stock.

As in other countries, the main disadvantage of trolleybuses in Poland was their dependence on the traction network and the associated limitations in the development of connections, as well as the need to maintain spare rolling stock in the form of diesel buses. Along with the development of alternative power sources, initially diesel generators, and then traction batteries, trolleybus carriers in Poland began to equip their rolling stock with such vehicles. Thanks to the new solution, each of the trolleybus networks in Poland is more extensive than it would appear from the traction infrastructure. Battery-powered trolleybuses run outside the network on out-run sections or with those with less frequent connections with little legitimacy of building the network infrastructure.

The implementation of electric buses poses a potential threat to the functioning of trolleybus transport in these cities. From the social point of view, an electric bus has the same advantages as a trolleybus and does not require additional infrastructure, which in itself, is often negatively perceived. Electric buses are currently being introduced in all three cities that have trolleybus transport. In the case of Gdynia, this is particularly unfavorable because deregulation of urban transport and splitting the municipal carrier into separate companies (two trolleybus and a bus ones) leads to intra-city competition [62]. Electric buses are introduced by a bus operator. With very extensive traction infrastructure, it would be possible to successfully service almost the entire city area using trolleybuses with on-board batteries of different capacities $[20,21]$. Due to the ease of obtaining external funds for electric buses and due to political difficulties (e.g., the activity of trade unions), it is impossible to delegate transport tasks to the company responsible for trolleybus transport without 
limitations. The transportation structure in Lublin and Tychy is slightly different. There is one municipal operator in Lublin, so it can easily change bus lines into trolleybus lines or retrofit the rolling stock with electric buses using common power infrastructure. However, the process of putting electric buses into operation in Lublin has been unsuccessful, because in 2008-2020 the length of the traction network doubled, which means that with a star-shaped city layout, practically all connections could be served by trolleybuses [19,62]. In Tychy, the principle was adopted that the trolleybus operator is responsible for all electric vehicles, so the new electric buses were also purchased by the trolleybus company [38].

6.2.3. Warsaw (Introduction of Electric Buses to Operation in a Large City with an Extensive Tramway Infrastructure)

Warsaw is the largest Polish city with an extensive public transport system. On a Polish scale, it is the city that spends the highest percentage of the annual budget on public transport, thanks to which the transport system of Warsaw is perceived as well-functioning and friendly to both residents and tourists [63]. Within the public transport system, there are two subway lines, an extensive tramway network, bus transport and integrated rail connections (fast city rail and Warsaw commuter railway). Until 1995, trolleybus transport (one line) operated between Warsaw and Piaseczno. In view of the necessity of its financing by two local government units and of decapitalization of the rolling stock, this system was abandoned and replaced by diesel buses [39]. Currently, Warsaw has the largest fleet of electric buses. After the delivery of 130 articulated Solaris buses, as well as earlier deliveries of standard Solaris and Ursus buses, many connections are served exclusively by this type of vehicle. In Warsaw, as in Gdynia, there are separate companies responsible for bus and tramway transport. Electric buses are operated by a bus operator. In the case of such a large scale and such a large urban center with an appropriate technical base, in particular the engineering one, there are not many limitations. The most important problem concerns the lack of in-depth studies on the legitimacy of introducing a large fleet of electric buses at one time. With equally regular use, the problem of replacing traction batteries may arise in the future. Due to its flat surface area, Warsaw has very good conditions for the functioning of trolleybus and tramway transport. The implementation of electric buses may jeopardize the further expansion of systems with greater durability and reliability.

6.2.4. Zielona Góra (Introduction of Electric Buses to Operation in a Large City which did Not Have Other Means of Electric Public Transport)

In Zielona Góra, the problem of the lack of pro-ecological public transport was identified. In the first decade of the 21st century, steps were taken to launch trolleybus transport. The high financial outlays related to the construction of the traction infrastructure prevented the authorities of Zielona Góra from taking a decision to make such an investment. Currently, it is a city with one of the largest fleets of electric buses. The Polish manufacturer Ursus won the tender for the supply of 47 standard buses. Due to this manufacturer's financial problems, 43 buses were delivered instead of 47. Thus Zielona Góra is a city with the largest number of buses of this brand. Due to the production shutdown in 2019 and the specter of bankruptcy, the carrier operating electric buses was left without support in terms of spare parts or even warranty service work. Therefore, it is an example showing that the process of purchasing electric buses should be extended in time, and the criteria related to quality and technology, as well as experience, should dominate in evaluating offers.

6.2.5. Szczecinek (Introduction of Electric Buses into Operation in a Small Town which did Not Have Other Means of Electric Public Transport)

As in the case of Zielona Góra, Ursus electric buses are also operated in Szczecinek. However, unlike Zielona Góra, which is a voivodeship city with a large municipal carrier, Szczecinek is a small city $(40,000$ inhabitants) without any significant scientific and technical facilities. In the case of operating buses whose manufacturer has actually ceased to exist, the life of the vehicles and the ability to maintain them in a good technical condition are the key issues. Small urban centers should seek cooperation with larger carriers or integrate 
orders together. With a larger pool of ordered vehicles, it is more likely to have greater competition among suppliers, and there is a possibility of obtaining a better offer or a more predictable one.

\section{Results of the Survey on the Perception of Electric Public Transport}

As part of the study, an attempt was made to identify the social perception of electric urban transport using an online questionnaire distributed among internet groups on Facebook-like portals of inhabitants of small, medium and large cities. The study consisted of six extensive questions on everyday mobility, preferences in choosing the type of public transport vehicle, opinions on the impact of the use of electric vehicles in public transport on various aspects of functioning in the city, and preferences regarding the policy of urban transport development.

The survey was designed to investigate to what extent the current activities of the Government in the field of electromobility development, mainly based on electric buses, are reflected in the preferences of the inhabitants. When analyzing transport development plans or studies on the validity of introducing electric buses, one can find expressions that indicate a negative perception of infrastructure (traction, tracks). In the daily press there were also articles (e.g., in Gdynia) concerning the opinion of the inhabitants on the negative impact of the existence of trolleybus traction infrastructure on the prices of apartments. In fact, the situation should be the opposite, and for this purpose, it was decided to prepare a survey to verify these hypotheses. Although at a first glance, the survey is to a small extent, related to the rest of the article, and in fact, it is of great importance for identifying the actual preferences of residents and formulating recommendations.

A total of 453 responses were obtained from adults in the period from 8 January to 7 February, 2021. Table 2 presents the respondents' characteristics with a breakdown by gender, age, education level and place of residence. The preface to the survey emphasized that the responses should include persistent preferences that would not consider the impact of the SARS-CoV-2 pandemic.

Table 2. Characteristics of the survey respondents $(n=453)$.

\begin{tabular}{|c|c|c|}
\hline Feature & Answers & Share \\
\hline \multirow{2}{*}{ Gender } & Female & $190(42 \%)$ \\
\hline & Male & $263(58 \%)$ \\
\hline \multirow{5}{*}{ Age } & $18-29$ & $150(33 \%)$ \\
\hline & $30-39$ & $145(32 \%)$ \\
\hline & $40-49$ & $92(20 \%)$ \\
\hline & $50-64$ & $40(9 \%)$ \\
\hline & 65 or above & $26(6 \%)$ \\
\hline \multirow{4}{*}{ Level of education } & Primary & $15(3 \%$ \\
\hline & Vocational & $7(2 \%)$ \\
\hline & Secondary & $79(17 \%)$ \\
\hline & Higher & $352(78 \%)$ \\
\hline \multirow{5}{*}{ Place of residence } & A city with its own public transport system & $367(81 \%)$ \\
\hline & A town served by the public transport of a nearby city & $28(6 \%)$ \\
\hline & A village served by the public transport of a nearby city & $29(7 \%)$ \\
\hline & A town without a public transport system & $6(1 \%)$ \\
\hline & A village without access to public transport & $23(5 \%)$ \\
\hline
\end{tabular}

The first question concerned the respondents' transportation behaviors. It was comprised of multiple sub-questions. The division into walking, cycling, the use of public 
transport, private or company car and other forms of shared transport, e.g., cars per minute, was applied. Walking, including reaching other means of transport, was the dominant form of everyday travel. Slightly over $24 \%$ of the respondents replied that they use public transport every day, and this value was clearly lower than using a private or company car (less than 31\%) (Figure 4). Over 24\% of the respondents gave an answer "once a month" to the question about using public transport. A total of $17 \%$ of the respondents do not use cars, and just over $12 \%$ do not use public transport. Shared vehicles were the least popular. In total, only over $19 \%$ of the respondents use this form of travel more than once a month. Over $43 \%$ of the surveyed persons never use such means of transport.

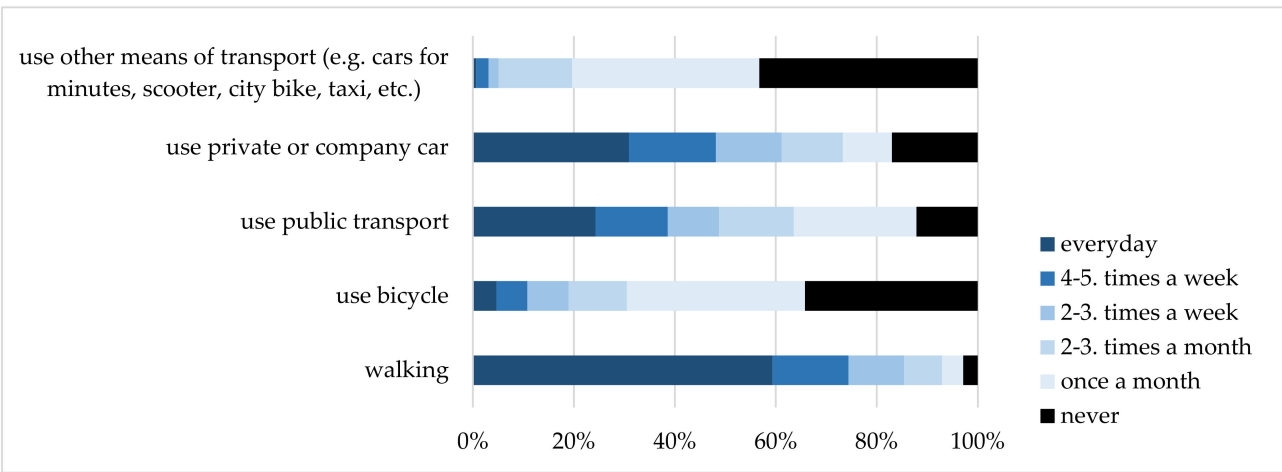

Figure 4. Characteristics of the respondents' transportation behaviors.

In the next question, an attempt was made to identify the respondents' preferences with regard to the choice of the means of public transport (Figure 5). The question was related to the hypothesis that the society considers its behavior to be pro-ecological, and the tramway has the highest rating in this regard. Due to the low level of their use, trolleybuses are not popular in Poland, which should be reflected in the answers. However, electric buses are gaining in importance and have become a popular political topic in recent years. The question was structured as follows: "let's assume that any vehicle (including trams and trolleybuses) can drive to the stop from which you are planning to leave. If you had a choice which vehicle would show up, what would you like to travel by the most? Let us add that the travel time and its cost would be the same for all vehicles." Over $42 \%$ of the respondents indicated the tram, just over $7 \%$ the trolleybus, and as many as over $28 \%$ the electric bus. Only $4.64 \%$ of the respondents indicated a diesel bus. For just under $18 \%$ of the respondents, the type of vehicle did not matter. The study indicated that nearly $80 \%$ of the respondents declared a pro-ecological choice.

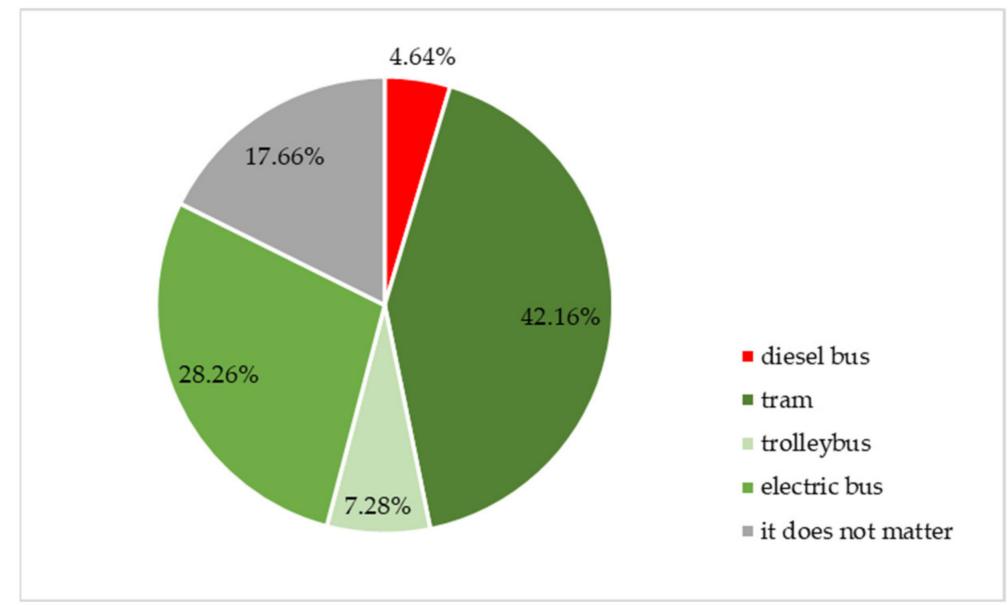

Figure 5. Preferences in the choice of means of public transport. 
The third question depended on the previous one. Respondents were asked to provide an answer regarding the factors of selecting the vehicle from the second question (Figure 6). A maximum of two features could be checked. A lower impact on the environment, lower noise emissions, adaptation for people with reduced mobility, as well as a clean interior, modernity and comfort of the vehicle were included in the list. Two options yielded the greatest number of responses. A total 191 respondents indicated the lower environmental impact and the same number the vehicle comfort. An important conclusion from the answers is that the people taking part in the survey do not treat lower noise emissions on the same level as the lower environmental impact. Electric vehicles are characterized by lower noise emissions, which is one of their main advantages.

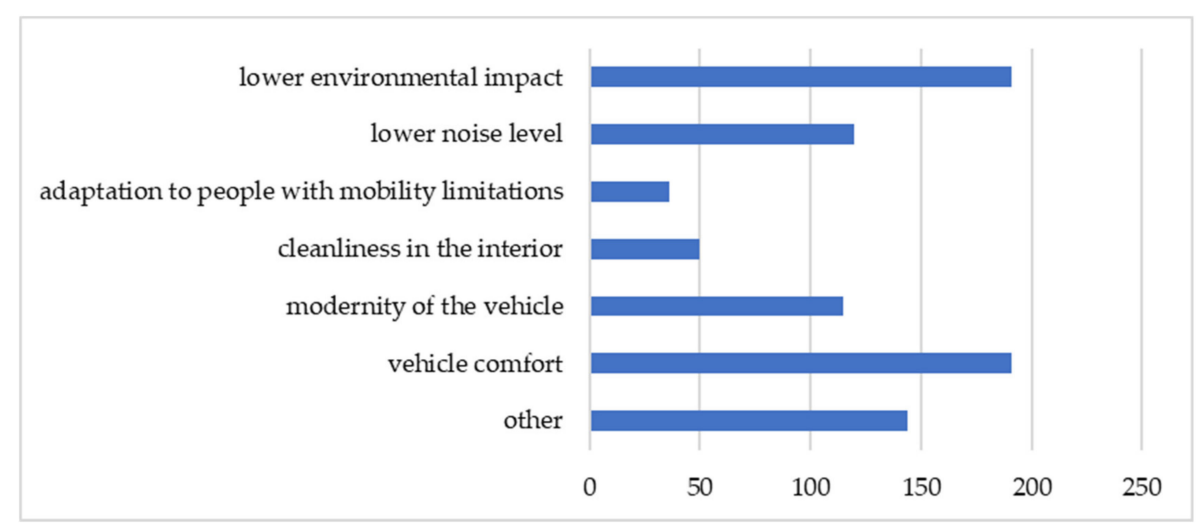

Figure 6. Factors of selecting means of public transport.

Answers to the next question allow us to deepen the knowledge about the respondents' preferences in regards to electric vehicles in public transport. The issue concerned the impact of the use of such means of transport on various organizational and functional aspects, both related to travel, vehicles and life in the city. For each aspect, one had to choose one of the options "increase", "has no effect" or "reduce". The obtained responses proved considerable public awareness of the positive impact of electric transport on the place of its operation. In two categories: noise and pollution, approx. $85 \%$ of the responses proved knowledge about the reduction of emissions thanks to the use of electric vehicles. Simultaneously, $74 \%$ of the respondents believed that this type of vehicle affects improvements in climate protection. Among the responses regarding the travel cost and time, responses indicating "no effect" dominated, although in fact there is a priority for trams in Polish cities, thanks to separate tracks. Information that for the majority of respondents (over 52\%), the existence of collective electric transport infrastructure did not affect the city's aesthetics is also vital. Almost $58 \%$ of the respondents indicated that the use of electric vehicles in public transport increases the comfort of travel (Figure 7).

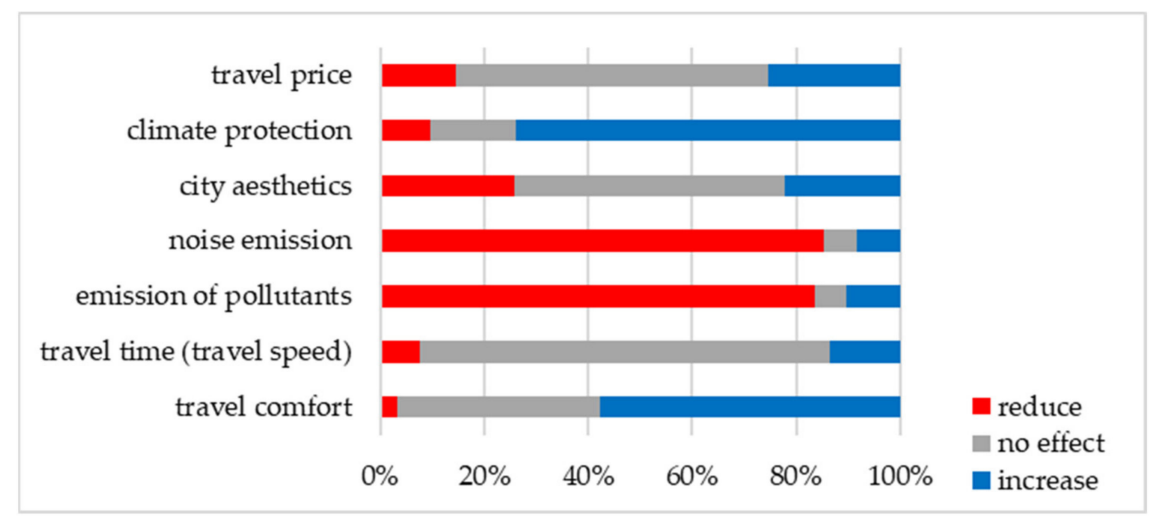

Figure 7. Assessment of the impact of the use of electric vehicles in public transport on various aspects of functioning. 
The next question was also extensive. It was used to identify public opinion on the impact of the existence of electric transport infrastructure (tramway tracks, trolleybus traction) on living conditions (Figure 8). Road safety, ease of socializing, aesthetics of public spaces, prestige of the place of residence, value of the property and certainty/durability of the existence of public transport were indicated as the features that might be affected by the functioning of public transport. The last four seem to be particularly important. Respondents could mark one out of the six available options ("definitely has a positive effect," "rather has a positive effect," "has no effect," "rather has a negative effect," "definitely has a negative effect" and "don't know/hard to say"). Over 50\% of the responses indicating the positive impact were recorded for ease of socializing, prestige of the place of residence, value of the property and the certainty/durability of public transport. Particularly valuable data concern answers about the prestige of the place of residence and the value of the property. Over $67 \%$ and $72 \%$ of the respondents, respectively, answered that the existence of public transport infrastructure might increase the value of real estate and the prestige of the place of residence. In the media discourse in Poland, there are reports that contradict this image. The conducted research has shown that society's opinion, in this case, is the same as that expressed in developed countries. The feature related to the impact on the aesthetics of public spaces received the least positive responses. Less than $28 \%$ of the respondents indicated a positive effect, and approx. $33 \%$ of the responses concerned a negative effect and no effect. Therefore, the division of public opinion in this respect is even.

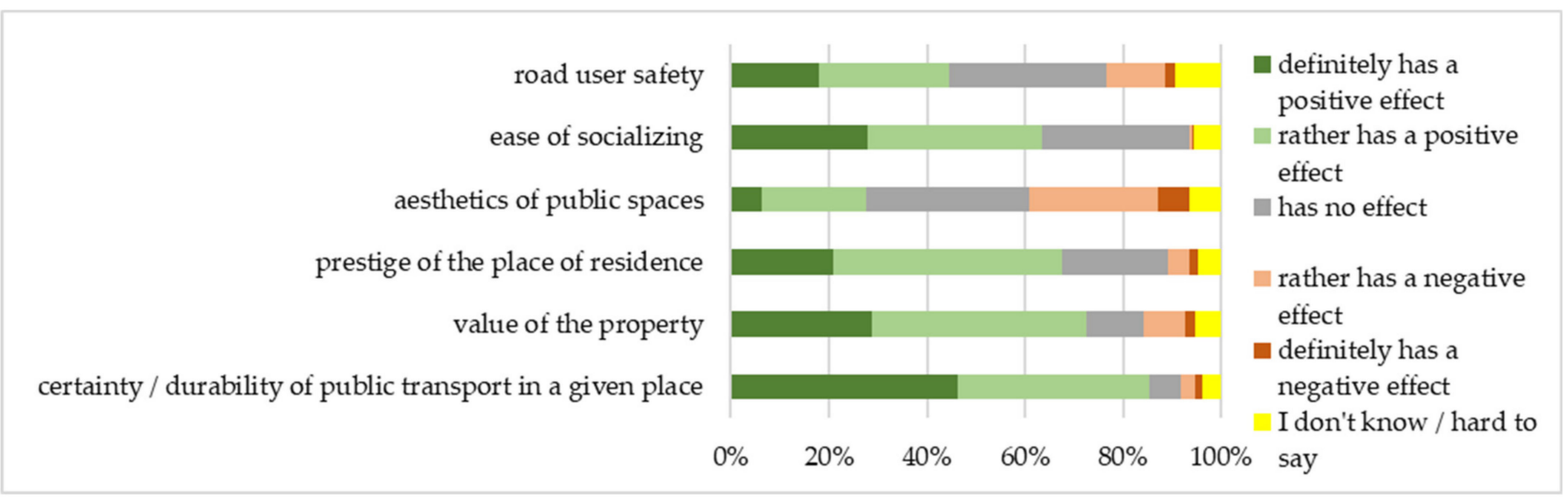

Figure 8. Assessment of the impact of the existence of electric public transport infrastructure (tracks, electric traction) on various aspects of inhabitants' lives.

The last discussed question concerned the development policy for public transport. The respondents were asked the following question: "Electric buses are almost twice as expensive as diesel buses. If your city authorities had a choice to buy five electric buses with the necessary infrastructure or to buy ten diesel buses (both investments would cost the same), which should be chosen in your opinion?" The answers were supposed to confirm the hypothesis that pro-ecological awareness prevails in the society, and media reports on the development of electric buses as well as their dynamic diffusion in Polish cities contribute to an increase in popularity of this means of transport. Analysis of the obtained responses allows us to conclude that the hypothesis has been confirmed (Figure 9). Most of the respondents chose the purchase of electric buses, despite their smaller number, and lower availability. Slightly less than $60 \%$ of the responses concerned this type of vehicle. Slightly over $20 \%$ of the respondents indicated diesel buses. For $3 \%$ of the respondents, the type of bus did not matter. Over $16.5 \%$ of the surveyed participants were unable to provide a specific answer. 


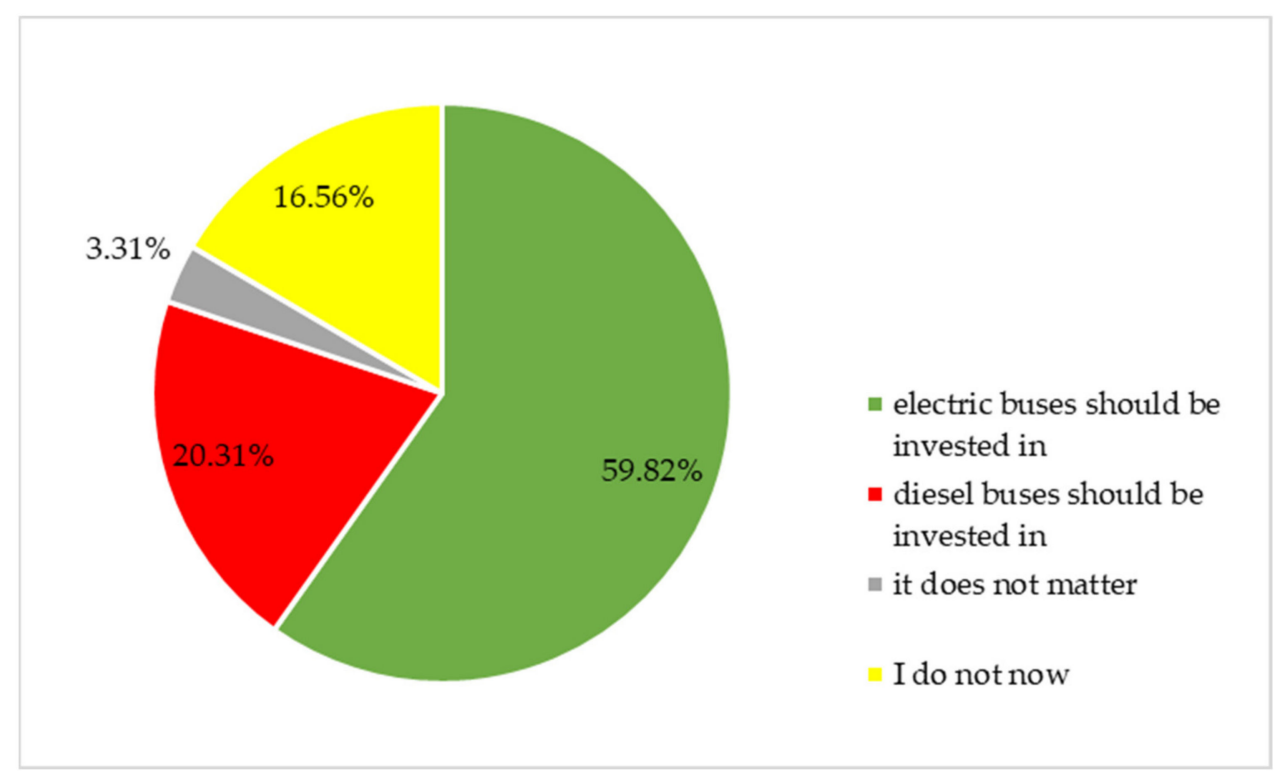

Figure 9. Respondents' opinions on the development policy of public transport.

Despite some limitations related to representativeness, the survey was an important source of information about the society's preferences and behavior as regards electric public transport. It enabled verifying several issues that appear in scientific studies but have not been verified in Poland so far, in particular, with regard to the relationship between electric transport infrastructure in cities and living conditions. The dynamic development of electric bus technology as well as government programs in Poland have contributed to the positive perception of electric buses. This is favorable in terms of holistic environmental protection and reducing emissions of pollutants, but at the same time it is a threat to traditional means of public transport (tramway, trolleybus). In-depth studies and analyses would allow us to avoid operational problems in the future. Society's positive opinion on investments in electric buses may make it difficult to undertake such activities by owners of transport companies, and in particular, by local authorities.

\section{Discussion and Conclusions}

Climate changes determine taking rapid measures to reduce emission of pollutants. The policy of the European Union, in this respect, has clearly defined the horizon of activities, indicating that the transport sector, including public transport, is one of the main spheres of the economy that must undergo transformation. By supporting initiatives related to electromobility in individual and collective transport, a significant part of the European Union budget is redirected to the modernization of fleets of vehicles and the construction of new systems, including infrastructure.

Polish adaptation activities in terms of the EU law at the level of government documents correspond to the assumptions of reducing emissions and sometimes even go further. Unfortunately, a poorly planned electromobility revolution in public transport leads to many distortions and loss of potential profits. The transformation of public transport in Poland is mainly related to subsidizing the purchase of electric buses and the infrastructure for charging them. Disregarding the energy balance of Poland, where fossil fuels, in particular-lignite and hard coal, are the main source of electricity production, the development of electric public transport and renewable energy sources should be combined to a greater extent $[64,65]$.

The ease of obtaining external funds for the purchase of electric buses encourages even the smallest towns to use this solution. The lack of a sufficiently long preparation process, in particular the assessment of the legitimacy of such actions, leads to a potential loss of the ability to maintain electric buses in the future. Failure to provide funds for their 
maintenance and for the replacement of exhausted batteries may lead to a decline in public transport.

The development of electric public transport in Poland is supported by programs (e.g., Gazela, Gepard) which are prepared with faults and do not enjoy the beneficiaries' trust or prevent equal competition [51-57]. In addition, the possibility of financing the development of trolleybus transport is disturbed in these programs, although for operational reasons the trolleybus is an equivalent means of transport in comparison to the electric bus [54].

Figure 10 presents a histogram of the development of electromobility in Poland in relation to public transport. Legislative changes also support the development of electric buses and trolleybuses manufactured in Poland. Both domestic producers and foreign brands with production plants in Poland have introduced this type of vehicles for sale.

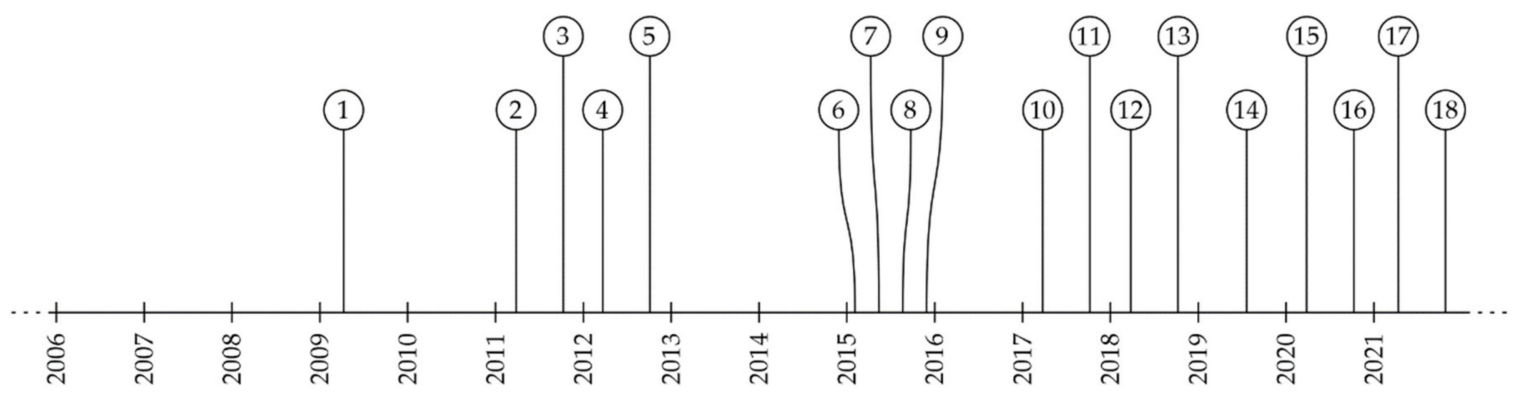

1. First trolleybuses with on-board batteries are put into operation (Gdynia)

2. The first trolleybuses with a combustion unit are put into operation (Lublin)

3. The prototype of the first domestic electric bus of the Solaris brand

4. Project „Gazela”

5. The prototype of the first domestic electric bus of the AMZ brand (later as URSUS)

6. Introduction of the first electric buses to use in public transport
7. Launch of the tram system in Olsztyn

8 . The prototype of the first domestic electric bus of the URSUS brand

9. The prototype of the bus of the Volvo brand (a foreign brand produced in Poland)

10. The document "National framework for the policy of alternative fuels infrastructure development"

11. Project "Gepard I"

12. Act on electromobility
13. Project "Gepard II"

14. The prototype of the first domestic electric bus of the RAFAKO brand (in cooperation with Industrial Development Agency)

15. The prototype of the bus of the MAN brand (a foreign brand produced in Poland)

16. The prototype of the first domestic electric bus of the Autosan brand 17. Project "Green Public Transport”

18. Amendment to the Act on electromobility

Figure 10. Histogram of the development of electromobility in public transport in Poland.

The most important threats to the development of electric public transport in Poland include the lack of an appropriate process of designing, implementing and gaining experience. Acquisition of vehicles in the technology with which there has not been experience so far, especially in the case of very small, provincial urban centers, may increase the costs of functioning of public transport [56]. The operation of electric buses in large cities, especially those with a different electric transport system, is much simpler, but also in this case there are controversial actions. The introduction of electric buses in cities with extensive trolleybus traction infrastructure constitutes unnecessary internal competition. The emphasis on the promotion of electric buses in Poland results in raising social awareness of environmental protection and in high evaluation of electric buses. The conducted survey proved that the purchase of five electric buses is more valuable to society than the purchase of ten diesel buses. At the same time, however, the existence of electric transport infrastructure affects the system's durability of operation, which should be particularly important for authorities of city with trolleybus transport which introduce electric buses into operation.

Lower emissions of $\mathrm{CO}_{2}$ and other pollutants to the environment are among the most important advantages of the development of electric public transport in Poland. Despite the negative energy balance, the operation of zero-emission vehicles in cities and densely populated areas will definitely affect the quality of life. Supporting the development of buses manufactured in Poland additionally strengthens the country's strong position in the European Union on the market of manufacturers of rolling stock for public transport $[45,46]$. 
Polish efforts to increase electromobility in public transport compared to other countries in the Central and Eastern Europe region should be appreciated. The intensity and scope of activities is very large despite the critical analysis presented in this article. Poland, as the main beneficiary of funds from the EU cohesion fund, had a chance to transform public transport on a large scale. With regard to other countries, some differences are noticeable. In particular, it should be emphasized that trolleybus systems in the Czech Republic, Slovakia, Romania and Bulgaria are dynamically developed. The most spectacular issue is currently raised in Prague, where a decision was made to build a very large trolleybus system from scratch. These types of actions can signal smaller cities to take similar steps. A similar phenomenon occurs in Iasi, Romania, where trolleybuses have not been operating since 2006. The local authorities have prepared a plan to purchase 50 trolleybuses and build the trolleybus traction infrastructure from scratch, motivating these activities with greater legitimacy in relation to electric buses.

Author Contributions: Conceptualization, M.P.; methodology, M.P.; formal analysis, M.P.; investigation, M.P.; resources, M.P. and P.W.; data curation, M.P. and P.W.; writing-original draft preparation, M.P. and P.W.; visualization, M.P.; supervision, M.P.; project administration, M.P.; funding acquisition, M.P. All authors have read and agreed to the published version of the manuscript.

Funding: The research was funded by a grant from the Polish National Science Centre (No. 2016/23/ D/HS4/03085).

Institutional Review Board Statement: Not applicable.

Informed Consent Statement: Not applicable.

Data Availability Statement: Not applicable.

Conflicts of Interest: The authors declare no conflict of interest.

\section{References}

1. Pejšova, M. Environmentally Friendly Public Transport. Trans. Transp. Sci. 2014, 7, 153-160. [CrossRef]

2. Biresselioglu, M.E.; Kaplan, M.D.; Yilmaz, B.K. Electric mobility in Europe: A comprehensive review of motivators and barriers in decision making processes. Transp. Res. Part A 2018, 109, 1-13. [CrossRef]

3. Burchart-Korol, D.; Gazda-Grzywacz, M.; Zarebska, K. Research and Prospects for the Development of Alternative Fuels in the Transport Sector in Poland: A Review. Energies 2020, 13, 2988. [CrossRef]

4. Pietrzak, O.; Pietrzak, K. The Economic Effects of Electromobility in Sustainable Urban Public Transport. Energies 2021, 14, 878. [CrossRef]

5. Pietrzak, K.; Pietrzak, O. Environmental Effects of Electromobility in a Sustainable Urban Public Transport. Sustainability 2020, 12, 1052. [CrossRef]

6. Tucki, K.; Orynycz, O.; Świć, A.; Mitoraj-Wojtanek, M. The Development of Electromobility in Poland and EU States as a Tool for Management of $\mathrm{CO}_{2}$ Emissions. Energies 2019, 12, 2942. [CrossRef]

7. Klucininkas, L.; Matulevicius, J.; Martuzevicius, D. The life cycle assessment of alternative fuel chains for urban buses and trolleybuses. J. Environ. Manag. 2012, 99, 98-103. [CrossRef] [PubMed]

8. Ajanovic, A.; Reinhard, H. Dissemination of electric vehicles in urban areas: Major factors for success. Energy 2016, 115, 1451-1458. [CrossRef]

9. Andwari, A.M.; Pesiridis, A.; Rajoo, S.; Martinez-Botas, R.; Esfahanian, V. A review of Battery Electric Vehicle technology and readiness levels. Renew. Sustain. Energy Rev. 2017, 78, 414-430. [CrossRef]

10. Gao, Z.; Lin, Z.; LaClair, T.J.; Liu, C.; Li, J.M.; Birky, A.K.; Ward, J. Battery capacity and recharging needs for electric buses in city transit service. Energy 2017, 122, 588-600. [CrossRef]

11. Kühne, R. Electric buses-An energy efficient urban transportation means. Energy 2010, 35, 4510-4513. [CrossRef]

12. Perujo, A.; Van Grootveld, G.; Scholz, H. Present and Future Role of Battery Electrical Vehicles in Private and Public Urban transport. In New Generation of Electric Vehicles; Stevic, Z., Ed.; InTech: Rijeka, Croatia, 2012; pp. 3-25.

13. Wang, S.; Lu, C.; Liu, C.; Zhou, Y.; Bi, J.; Zhao, X. Understanding the Energy Consumption of Battery Electric Buses in Urban Public Transport Systems. Sustainability 2020, 12, 10007. [CrossRef]

14. Cansino, J.M.; Sánchez-Braza, A.; Sanz-Díaz, T. Policy Instruments to Promote Electro-Mobility in the EU28: A Comprehensive Review. Sustainability 2018, 10, 2507. [CrossRef]

15. Costa, Á.; Fernandes, R. Urban public transport in Europe: Technology diffusion and market organization. Transp. Res. Part A 2012, 46, 269-284. [CrossRef] 
16. Krawiec, K. Proces wprowadzania autobusów elektrycznych do eksploatacji w przedsiębiorstwach komunikacji miejskiejWybrane zagadnienia. Pr. Nauk. Politech. Warsz. 2016, 112, 217-226.

17. Krawiec, S.; Krawiec, K. Rozwój elektromobilności w Polsce. Uwarunkowania, cele i bariery. Zesz. Nauk. Uniw. Ekon. Katowicach 2017, 332, 17-21.

18. Brdulak, A.; Chaberek, G.; Jagodziński, J. Development Forecasts for the Zero-Emission Bus Fleet in Servicing Public Transport in Chosen EU Member Countries. Energies 2020, 13, 4239. [CrossRef]

19. Hołyszko, P.; Filipek, P.Z. Estimation of the running costs of autonomous energy sources in trolleybuses. J. Ecol. Eng. 2016, 17, 101-106. [CrossRef]

20. Wołek, M.; Szmelter-Jarosz, A.; Koniak, M.; Golejewska, A. Transformation of Trolleybus Transport in Poland. Does In-Motion Charging (Technology) Matter? Sustainability 2020, 12, 9744. [CrossRef]

21. Wołek, M.; Wolański, M.; Bartłomiejczyk, M.; Wyszomirski, O.; Grzelec, K.; Hebel, K. Ensuring sustainable development of urban public transport: A case study of the trolleybus system in Gdynia and Sopot (Poland). J. Clean. Prod. 2021, 279, 123807. [CrossRef]

22. Alfieri, L.; Bracale, A.; Caramia, P.; Iannuzzi, D.; Pagano, M. Optimal battery sizing procedure for hybrid trolley-bus: A real case study. Electr. Power Syst. Res. 2019, 175, 105930. [CrossRef]

23. Barłłomiejczyk, M.; Połom, M. Dynamic Charging of Electric Buses as a Way to Reduce Investment Risks of Urban Transport System Electrification. In Transbaltica Xi: Transportation Science and Technology, Proceedings of the International Conference Transbaltica, Vilnius, Lithuania, 2-3 May 2019; Gopalakrishnan, K., Prentkovskis, O., Yatskiv, I., Junevičius, R., Eds.; Springer Nature Switzerland AG: Cham, Switzerland, 2020; pp. 297-308.

24. Berigk, F.; Biemann, K.; Lambrecht, U.; Pütz, R.; Landinger, H. Potential of In-Motion Charging Buses for the Electrification of Urban Bus Lines. J. Earth Sci. Geotech. Eng. 2016, 6, 347-362.

25. Pieriegud, J. E-mobility as a concept of network industry development. In E-Mobility: Visions and Development Scenarios; Gajewski, J., Paprocki, W., Pieriegud, J., Eds.; Coalition for Strategic Mindset: Sopot, Poland, 2017; pp. 9-20.

26. Zawieska, J. E-mobility in transport and climate policies of European Union and Poland. In E-Mobility: Visions and Development Scenarios; Gajewski, J., Paprocki, W., Pieriegud, J., Eds.; Coalition for Strategic Mindset: Sopot, Poland, 2017; pp. 23-39.

27. United Nations. Analysis of the Transport Relevance of Each of the 17 SDGs; Draft report of the Technical Working Group on Transport; United Nations: New York, NY, USA, 2016.

28. World Bank. Atlas of Sustainable Development Goals 2017: From World Development Indicators; World Bank: Washington, DC, USA, 2017.

29. European Commission. General Union Environment Action Programme to 2020. Living Well, within the Limits of Our Planet; European Commission: Luxembourg, 2014.

30. European Commission. Europe 2020. A Strategy for Smart, Sustainable and Inclusive Growth, COM (2010) 2020 Final; European Commission: Brussels, Belgium, 2010.

31. European Commission. Energy Roadmap 2050, COM (2011) 885 Final; European Commission: Brussels, Belgium, 2011.

32. European Commission. A Roadmap for Moving to a Competitive Low Carbon Economy in 2050, COM (2011) 112 Final; European Commission: Brussels, Belgium, 2011.

33. European Commission. White Paper. Roadmap to a Single European Transport Area-Towards a Competitive and Resource Efficient Transport System, COM (2011) 144 Final; European Commission: Brussels, Belgium, 2011.

34. European Commission. Together towards Competitive and Resource-Efficient Urban Mobility, COM (2013) 913 Final; European Commission: Brussels, Belgium, 2013.

35. European Commission. A European Strategy for Low-Emission Mobility, COM (2016) 501 Final; European Commission: Brussels, Belgium, 2016.

36. European Commission. Communication from the Commission to the European Parliament, the European Council, the Council, the European Economic and Social Committee and the Committee of the Regions, The European Green Deal, COM (2019) 640 Final; European Commission: Brussels, Belgium, 2019.

37. European Commission. Communication from the Commission to the European Parliament, the Council, the European Economic and Social Committee and the Committee of the Regions, Sustainable and Smart Mobility Strategy-Putting European Transport on Track for the Future, COM (2020) 789 Final; European Commission: Brussels, Belgium, 2020.

38. Borowik, L.; Cywiński, A. Modernization of a trolleybus line system in Tychy as an example of eco-efficient initiative towards a sustainable transport system. J. Clean. Prod. 2016, 117, 188-198. [CrossRef]

39. Połom, M. Przemiany Funkcjonowania Komunikacji Trolejbusowej w Polsce w Latach 1989-2013; Wydawnictwo Bernardinum: Pelplin, Poland, 2019; pp. 1-284.

40. Górny, J.; Połom, M. Rozwój infrastruktury tramwajowej w Polsce w okresie członkostwa w Unii Europejskiej. TTS Tech. Transp. Szyn. 2015, 22, 20-36.

41. Kołoś, A.; Taczanowski, J. Fundusze europejskie jako czynnik rozwoju miejskiego transportu szynowego w Polsce. Pr. Kom. Geogr. Komun. PTG 2016, 19, 9-20.

42. Połom, M. European Union Funds as a Growth Stimulant of Electromobility on the Example of Electric Public Transport in Poland. Barom. Reg. Anal. Progn. 2015, 13, 89-96.

43. Kołoś, A.; Taczanowski, J. The feasibility of introducing light rail systems in medium-sized towns in Central Europe. J. Transp. Geogr. 2016, 54, 400-413. [CrossRef] 
44. Taczanowski, J.; Kołoś, A.; Gwosdz, K.; Domański, B.; Guzik, R. The development of low-emission public urban transport in Poland. Bull. Geogr. Socio-Econ. Ser. 2018, 41, 79-82. [CrossRef]

45. Połom, M. Spatial aspects of the production and export of buses in Poland in the years 1989-2014. Stud. Ind. Geogr. Comm. Pol. Geogr. Soc. 2015, 29, 56-72.

46. Połom, M. International Relations on the Market of Trolleybus' Manufacturers in Europe in the Years 2000-2014. Stud. Ind. Geogr. Comm. Pol. Geogr. Soc. 2017, 30, 75-90.

47. European Commission. Directive 2014/94/EU of the 22 October 2014 on the Deployment of Alternative Fuels Infrastructure; European Commission: Brussels, Belgium, 2014.

48. European Commission. National Framework for the Policy of Development of Alternative Fuel Infrastructure; Resolution of the Council of Ministers from 29 March 2017; European Commission: Brussels, Belgium, 2017.

49. ZDG TOR; National Center for Research and Development. Polska na Drodze do Elektromobilności; ZDG TOR: Warszawa, Poland, 2018.

50. International Energy Agency. Act on Electromobility and Alternative Fuels from 11 January 2018; International Energy Agency: Paris, France, 2018.

51. Urbanowicz, W. MPK Częstochowa z Przetargiem na Doprowadzenie do Sprawności Hybrid. Available online: https://www. transport-publiczny.pl/wiadomosci/mpk-czestochowa-z-przetargiem-na-doprowadzenie-do-sprawnosci-hybryd-67113.html (accessed on 18 February 2021).

52. Gepard Następcą Gazeli. 200 Mln zł na Elektrobusy. Available online: https://transinfo.pl/infobus/gepard-nastepca-gazeli-200mln-zl-na-elektrobusy-_more_97410/(accessed on 17 February 2021).

53. 30 Elektrobusów z Geparda dla 5 Polskich Miast. Available online: https://transinfo.pl/infobus/30-elektrobusow-z-gepardadla-5-polskich-miast-_more_102769/(accessed on 17 February 2021).

54. Gepard-Bezemisyjny Transport Publiczny. Available online: http://nfosigw.gov.pl/oferta-finansowania/system-zielonychinwestycji---gis/konkursy/czesc-2-gepard---bezemisyjny-transport-publiczny/ (accessed on 16 February 2021).

55. Gepard II-Transport Niskoemisyjny, Część 3, Śląsk-Zagłębie Bezemisyjnego Transport Publicznego. Available online: http://nfosigw.gov.pl/oferta-finansowania/srodki-krajowe/programy-priorytetowe/gepard-ii--transport-niskoemisyjnyczesc-2/gepard-ii--transport-niskoemisyjny-czesc-3-slask-/ (accessed on 18 February 2021).

56. Zielony Transport Publiczny. Available online: http://nfosigw.gov.pl/oferta-finansowania/srodki-krajowe/programypriorytetowe/zielony-transport-publiczny-faza-i/ (accessed on 17 February 2021).

57. Urbanowicz, W.; Koniec Naboru w Programie Zielony Transport Publiczny. Pula 1,1 Mld zł Wyczerpana. Available online: https:/ / www.transport-publiczny.pl/wiadomosci/koniec-naboru-w-programie-zielony-transport-publiczny-pula-11-mldzl-wyczerpana-67278.html (accessed on 17 February 2021).

58. Ciesielski, M. Olsztyn: Poland's first new tramway in 50 years. Tramw. Urban Transit 2012, 75, 454-456.

59. Goliszek, S.; Połom, M. The impact of the construction of a new tram line in Olsztyn to change the accessibility of public transport. Acta Sci. Pol. Adm. Locorum 2016, 15, 19-34.

60. Świdyński, J. Zintegrowany system transportu zbiorowego na przykładzie Olsztyna. Zesz. Nauk. Uniw. Gdańskiego Ekon. Transp. Logistyki 2017, 62, 97-105.

61. Grzymowicz: Tramwaje Stały się Marką Olsztyna. Available online: https://www.transport-publiczny.pl/wiadomosci/ grzymowicz-tramwaje-staly-sie-marka-olsztyna-59955.html (accessed on 10 February 2021).

62. Połom, M. Trends in the development of trolleybus transport in Poland at the end of the second decade of the 21st century. Pr. Kom. Geogr. Komun. PTG 2018, 21, 44-59. [CrossRef]

63. Warszawa Wydaje na Transport Publiczny Najwięcej w Polsce. Czy Mieszkańcy Czują Tego Efekty? Available online: https: / / warszawa.naszemiasto.pl/warszawa-wydaje-na-transport-publiczny-najwiecej-w-polsce/ar/c4-4620769 (accessed on 18 February 2021).

64. Marks-Bielska, R.; Bielski, S.; Pik, K.; Kurowska, K. The Importance of Renewable Energy Sources in Poland's Energy Mix. Energies 2020, 13, 4624. [CrossRef]

65. Wierzbowski, M.; Filipiak, I.; Łyżwa, W. Polish energy policy 2050-An instrument to develop a diversified and sustainable electricity generation mix in coal-based energy system. Renew. Sustain. Energy Rev. 2017, 74, 51-70. [CrossRef] 